\title{
Distribution of Holiday and Recreation Settlements in the Danube Basin From Belgrade to Prahovo
}

\section{Popović, Ivan'}

\begin{abstract}
Observed within the frame of macro-geographical dimensions, the Danube Basin in Serbia belongs to the Pannonian (Middle) Danube Basin. In its larger, southeastern part, the course of the Danube forms the territorial border between the parts of Serbia (on the south) and Romania (on the north). As a spatial entity, this integral part of the Middle Danube Basin is divided into the northern Danube riverside which belongs to Romania, and the southern, which belongs to Serbia. Due to its position on western end of peri-Pannonian Serbia, and to the Danube water current respectively, such extended border area has been interesting altogether for construction of buildings and even settlements intended for holiday and recreation purposes. Initiated mainly by the objective social factors (particular and general) and to a certain degree modified by subjective ones, the spatial distribution of such settlements (from the outskirts of Belgrade agglomeration to Prahovo) has not been particularly regular. Therefore, it is especially emphasized in this article that they are, unless the main spatial reason, the Danube course is neglected, most irregularly distributed both on its banks and in the nearer or farther riverside areas. This influenced their uneven distribution over the Danube alluvium and valley side, the valleys of its immediate tributaries and the Aeolian relief shapes, as well as on the edges of Ključ area and "rear" slopes of Miroč.
\end{abstract}

Key words: the Danube Basin, holiday and recreation settlements, distribution within municipal territories, macro and mezzo findings of the Danube Basin settlements for holiday and recreation.

\footnotetext{
1 Ivan Popović

Geographical Institute "Jovan Cvijić" of Serbian Academy of Sciences and Arts, 9 Đure Jakšića, 11000 Belgrade, Serbia
}

\section{INTRODUCTION}

A very small, stretched border part of Serbia, i.e. such determined the Danube riverside, also includes the localities where holiday and recreation buildings have been gradually or hastily "gathered" within such settlements. As it could be expected, these settlements have been distributed, at different distances from one another, exclusively on the right valley side of the Danube. Since it is not equally attractive for this kind of construction, it is understandable why these settlements are more (or less) concentrated only in certain places - localities, in the parts of the Danube Basin.

Most holiday and recreation settlements, even 20 of them ("Žežnica", "Pajkovo brdo", "Ključevac", "Provalija", "Plavinci", "Lipovica”, “Tarabe”, "Prokop", "Careva glava”, "Cigansko brdo", "Dubočaj”, "Rujnište”, "Straževica”, "Dunavski venac", "Sedlarac", "Orešački topoljar”, "Jugovo", "Gvozdenglav", "Donje livade" and "Metalor") are situated at some "ends" of the northernmost part of Šumadija highlands, and also on the immediate alluvial plane of the Danube. Mainly on the noticeably farther downstream riverside, i.e. in some northernmost flat or levelled parts of northern and northeastern Stig and Braničevo, there are slightly fewer (15) settlements for holiday and recreation ("Rovine", "Šugavica-Kanal", "Skupica”, "Ušće”, "Sprud”, "Šajica”, "Kalinovac", "Kalinovčić I", "Kalinovčić II", "Rudarevo", "Beli bagrem", "Male humke", "Golubački peskovi", "Duga šuma" and "Ridan"). It is interesting that there are even as many concentrated in the joint riverside area of Kostolac, Veliko Gradište and Golubac. Their number is almost four times smaller ("Ciganija-Krapaćos", “Zlatica”, "Obljaga mare" and "Gradišnica") on terraced, but steeper terrains of the rather narrow, typical Đerdap riverside, i.e. the area around Donji Milanovac.

Farther down the river, in a little different topographically "shaped" area, 11 holiday and recreation settlements are situated ("Osojna”, "Streževica”, "Meja”, "Slatinski most", "Dobra voda", "Bare", "Poljana", "Blato", "Kula", "Barbulješće" and "Vrkanj”). Because it is considerably expanded, this area is, according to the above mentioned, justi- fiably divided into two unequal parts, which both belong to the northern (Kladovo) and the southern (Prahovo) division of the eastern Danube Basin. The northern Kladovo division includes four settlements ("Osojna", "Streževica", "Meja" and "Slatinski most", and additional three ("Dobra voda", "Bare" and "Poljana") which are far out the inherent riverside. The latter are not included in the southern Prahovo division because all of its settlements ("Blato", "Kula", "Barbulješće" and "Vrkanj") are situated on the immediate riverside area of the Danube.

Such number (50) of the Danube Basin holiday and recreation settlements on the one hand, and their unequal distribution over the Basin divisions on the other, inevitably support their division which is primarily based on their belonging to the municipal territories. This facilitates their basic division into holiday and recreation settlements (and colonies) of: Grocka ("Žežnica", "Pajkovo brdo", "Ključevac", "Lipovica", "Provalija", "Plavinci", "Tarabe”, "Prokop", "Careva glava", "Cigansko brdo", "Dubočaj”, "Rujnište”, "Straževica”, "Sedlarac" and "Dunavski venac"), Smederevo ("Orešački topoljar", "Jugovo", "Gvozdenglav", "Donje livade" and "Metalor"), Kostolac ("Rovine", "Šugavica-Kanal", "Skupica", "Ušće” and "Sprud”), Veliko Gradište ("Šajica”, "Kalinovac", "Kalinovčić I", "Kalinovčić II", "Rudarevo" and "Beli bagrem"), Golubac ("Male humke", "Golubački peskovi", 'Duga šuma" and "Ridan"), Donji Milanovac ("Ciganija-Krapaćos", "Zlatica”, "Obljaga mare" and "Gradišnica"), Kladovo ("Osojna", "Streževica", "Meja”, "Slatinski most", "Dobra voda", "Bare" and "Poljana") and Prahovo ("Blato", "Kula", "Barbulješće" and "Vrkanj”).

The above distribution within the municipal territories also raises the question of their uneven distribution over the Danube Basin (Popović I. B, 1988-1992, 19931999). Moreover, this is based on the fact that only a small percentage of them (4 or $8 \%)$ are situated in three municipalitiesGolubac, Majdanpek (Donji Milanovac) and Negotin (Prahovo), and a little higher percentage ( 5 or $10 \%$ ) in two municipalities - Smederevo and Požarevac (Kostolac). Furthermore, more settlements are situated within the municipalities of Veliko Gradište and Kladovo (6 or $12 \%$ and 7 


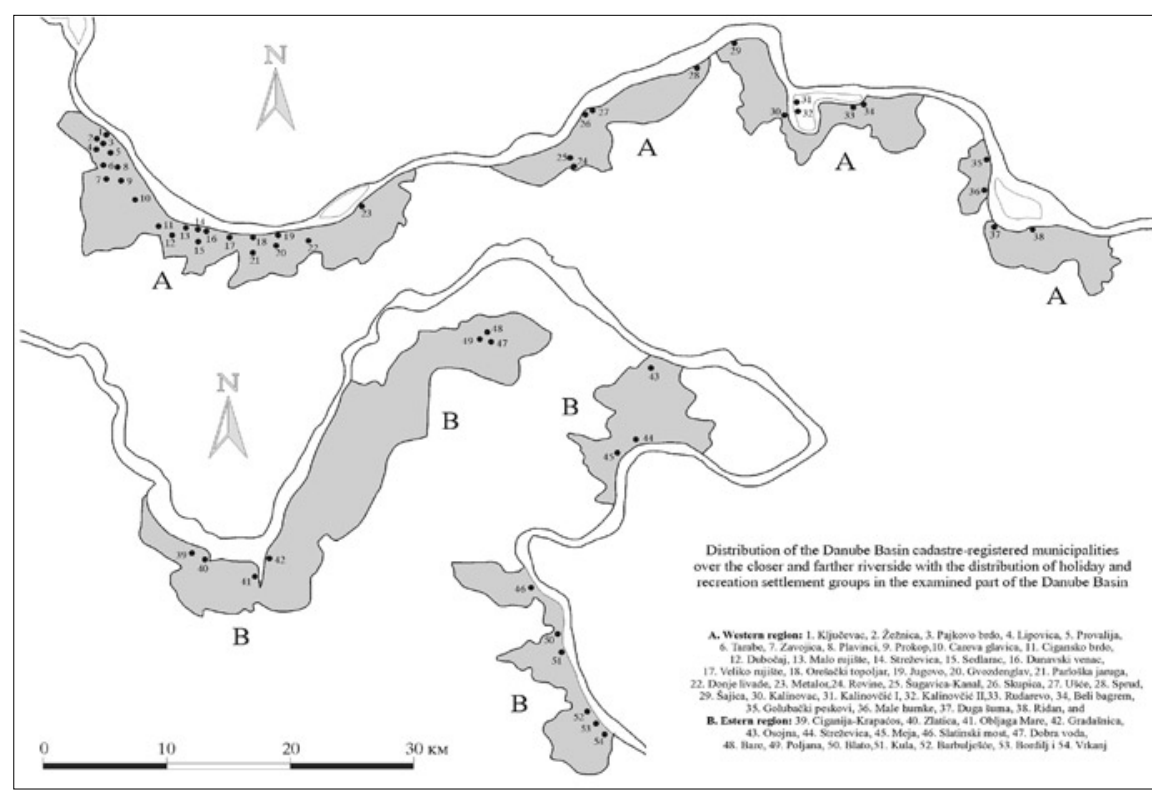

Figure 1 Map of recreation settlements in the Danube Basin from Belgrade to Prahovo

or $14 \%$, respectively), while it is considered natural that Grocka municipality comprises the largest number of them (15 or $30 \%$ ).

\section{Macro and mezzo localities of the danube basin holiday and recreation settlements}

The careful observation of each settlement separately renders the fact that most of them $(24$ or $48 \%)$ are situated in the valley of the Danube, as well as in the valleys of its immediate tributaries (Popović, 2003). As observed from the west towards the east, the former certainly includes both the northern ("Žežnica", "Pajkovo brdo" and "Ključevac") and the southern part ("Prokop" and "Careva glava") of the northwestern, as well as the eastern part ("Rujnište", "Straževica", "Sedlarac" and "Dunavski venac") of the southeastern Grocka settlements, but also one ("Lipovica") from the central part of the northwestern and one from the western part ("Cigansko brdo") of the southeastern Grocka settlements. In the neighbouring Smederevo municipality, there are only two such settlements ("Jugovo" and "Gvozdenglav") and there is also one in Golubac and one in Donji Milanovac ("Ridan" and "Ciganija-Krapaćos”, respectively).

The latter justifiably include the others from the central part ("Provalija", "Tarabe" and "Plavinci") and the part ("Dubočaj") of the southeastern Grocka settlements. Two settlements in Smederevo and Veliko Gradište ("Donje livade" and "Šajica", respectively) are also among them. It is interesting that they also include all the remaining settlements of Donji Milanovac ("Zlatica", "Obljaga mare" and "Gradašnica”).

Generally, it is obvious that the former represent 15 or $30 \%$, and the latter 9 or 18 $\%$ of all the Danube Basin settlements, i.e. every other settlement is denoted as "val- ley". Besides that, their "spatial arrangement" is connected with the more western Grocka-Smederevo, as well as rather eastern Donji Milanovac part of the Danube Basin, which indicates that such settlements do not exist not only among the others of Veliko Gradište and Golubac, but also among all the settlements of Kostolac, Kladovo and Prahovo.

According to their number, "valley settlements" are followed by those which are concentrated exclusively on the higher or lower level of the Danube alluvial plane (10 or $20 \%$ ). Appearing only in the lowlands of the Danube Basin, which are determined by the down courses of the Velika Morava (in the west) and the Pek (in the east), "lowlands" settlements differ from each other only in the height of this alluvium.

Thus, there is only one Smederevo settlement ("Orešački topoljar") on the lowest (inundated), i.e. periodically flooded alluvial level. The other Smederevo settlement ("Metalor") could also be such if it had not been reshaped by individuals who gradually covered it with slag (dross), which considerably helped it reach higher alluvial level, thus eliminating any possibility of flooding. The Kostolac settlement "Rovine" is very similar in reaching higher level, because its "alluvial locality" was also reshaped by piling slag from the nearby "Kostolac" mine.

The Kostolac ("Šugavica-Kanal", "Skupica", "Ušće" and "Sprud") and Veliko Gradište ("Kalinovac", "Kalinovčić I" and "Kalinovčić II") settlements include almost the same number (4 and 3) of other "lowlands" settlements of the Danube Basin. Although they occupy relatively higher alluvial level, they still, to a certain degree, differ in its "fluvial belonging". The Kostolac settlements lie on the typical Danube alluvium, while these of Veliko Gradište are exclusively located on the alluvium of its large former branch- Kisiljevski Dunavac, and, by its partition from the both sides, of today's Srebrno Jezero.

Compared to the "lowlands" settlements, there is a slightly smaller number of those (8 or $16 \%$ ) situated on or along the eastern edges of the area of Ključ, which means that they are connected with the easternmost riverside parts of the Danube Basin. Therefore it is understandable that they comprise most settlements of Kladovo ("Streževica", "Osojna", "Meja" and "Slatinski most") and all the settlements of Prahovo ("Blato", "Kula", "Barbulješće" and "Vrkanj”).

Apart from the above mentioned, the Danube Basin also comprises the settlements whose "macro- existing" is firmly connected with the well known shapes of the Aeolian relief (dunes and valleys). Since the Aeolian relief (the sands of Golubac and Veliko Gradište) is divided by the shallow river Pek valley into the northwestern (of Veliko Gradište) and southeastern (of Golubac) part, with mostly wide dunes (elevations) and valleys (depressions) between them, it is natural to expect that these settlements are situated on the municipal territories of both Veliko Gradište and Golubac. More precisely, there are such three colonies and the only two settlements in the Danube Basin, which make 5 or $10 \%$ of all its settlements. Territorially, "Rudarevo" colony and the settlement "Beli bagrem" belong to Veliko Gradište, while the settlement "Golubački peskovi" and two colonies ("Male humke" and "Duga šuma") belong to Golubac.

The smallest percentage ( 3 or $6 \%$ ) of the Danube Basin settlements are situated within their macrolocality on the "rear" slopes of Miroč. Concentrated near the deserted recreational and sport centre "Kraku Balta", three settlements ("Dobra voda", "Bare" and "Poljana") are incorporated into Miroč part of Kladovo settlements, which indicates their territorial belonging

Considering the fact that the Danube Basin is, in the narrow sense, large and almost complete spatial entirety, global dispersion of holiday and recreation settlements can be better perceived only through the prism of its most spread natural environmental features (Popović, 2003). The important mentioned natural features (the Danube valley side, the valley sides of its immediate tributaries, higher and lower level of the Danube alluvial plane, relief shapes of Golubac-Veliko Gradište sands, the edges of Ključ area and the "rear" slopes of Miroč) are also the basic "key features" for interpreting the settlement locations, which have been adequately called (Gosar, 1988) macrolocalities. Similar, but to some extent different macrolocalities of such settlements can also be seen in other parts of Serbia, which is another reason to appreciate them in finding the global features of these spatial phenomena. 
Since within these macrolocalities of the Danube Basin settlements, we can differentiate parts which are situated, in relation to the Danube flow, within its bank zone, either almost beside it (immediate, closer riverside), or rather away from it (indirect, farther riverside), such division can serve as the basis for better understanding of the spatial dispersion of settlements in the whole Danube Basin. More precisely, it enables the differentiation of settlements according to which of these three middle (mezzo) "segments" they belong, in each of the determined macrolocalities. Taking all of this into consideration, determining these mezzolocalities, i.e. determining the bank zone, immediate (closer) and indirect (farther) riverside settlements proved appropriate.

On the basis of available data from separate studies of the Danube Basin settlements, it can be emphasized, with some certainty, that they have rather uneven positions in relation to the Danube flow. They are sometimes positioned very close to it, then more often a little farther, although there are sometimes rather farther ones. Such are their mezzo positions not only within the whole Danube Basin, but also within almost each separate macrolocality.

For the correct understanding of their mezzolocalities (bank zone, closer and further riverside), it should not be forgotten that the bank zone of any larger water flow is considered to be (Jovičić, 1967; Gosar, 1988) the land along the bank which is $350 \mathrm{~m}$ wide, although there are some opinions that it can be up to $0.5 \mathrm{~km}$ wide, and sometimes even wider. According to these two opinions, it is accepted that the immediate (close) riverside must not be wider than $1.4-1.5 \mathrm{~km}$ and $2.0 \mathrm{~km}$, respectively, which clearly indicates that indirect (farther) riverside is meant to be beyond these dimensions. As the former opinion seemed geographically more valid from the aspect of our field experience, we adopted it in our considerations.

Adding the above mentioned into the knowledge about the settlement concentration in the determined macrolocalities in the Danube Basin, we can draw the general conclusion that they are least distributed (9 or $18 \%$ ) in the Danube bank zone, and twice as much ( 20 or $40 \%$ ) in its immediate (in further text - closer) riverside, but there is almost the equal percentage ( 21 or $42 \%$ ) in its indirect (in further text- farther) riverside. Concerning their macrolocalities in the Danube Basin, settlements are not situated in the bank zones which belong to the valley side of the Danube and the valley sides of its immediate tributaries. Also, there are not any bank zone settlements on the "rear" slopes of limestone Miroč.

As it could be supposed, such settlements are the most numerous within their macrolocality on the alluvial plane of the Danube ("Orešački topoljar", "Metalor",
"Skupica", "Ušće” and "Sprud"). They are followed by the equal numbers of these which belong to the macrolocalities on the shapes of Aeolian relief ("Rudarevo" and "Golubački peskovi") and on the edges of Ključ area ("Slatinski most" and "Kula"). It can also be said that mezzo bank zone localities of settlements are rather unequally distributed in the Danube Basin.

It is almost the opposite situation with the settlements from the mezzolocalities of the closer riverside, because they are, except for one, situated in all those closer riverside macrolocalities. Thus, in the closer riverside of the valley side of the Danube there are even six settlements, two of which ("Jugovo" and "Ridan") are positioned so close to its bank zone that they largely touch it alongside. The other four ("Ključevac", "Prokop", "Careva glava" and "Rujište") are situated at shorter or a little longer distances from the bank zone within closer riverside.

In the macrolocalities on both the valley sides of the Danube immediate tributaries and the edges of Ključ area there is the equal number of close riverside settlements, five in each ("Plavinci”, "Šajica”, "Zlatica”, "Obljaga mare" and "Gradašnica" in the former, and "Streževica", "Meja", "Blato", "Barbulješće" and "Vrkanj" in the latter). It is interesting that they all, except for one ("Plavinci"), partly penetrate into the inherent bank zone. Since the settlement "Plavinci" is a little farther from it, it represents a typical riverside settlement of the mentioned macrolocalities.

The macrolocalities of the Danube alluvial plane and the shapes of Aeolian relief include a significantly smaller number (4) of such riverside settlements, two of them each ("Šugavica-Kanal” and "Kalinovčić I" in the former and "Beli bagrem" and "Duga šuma" in the latter). They are also in such stronger contact with the inherent bank zone, that they partly even lie on it. Since such riverside settlements do not exist only on the slopes of Miroč, it can be said that they are more harmoniously concentrated than the former ones.

There is also a settlement mezzolocality in the Danube Basin which refers to their presence in farther riverside. As expected, the Danube valley side comprises the most of these settlements (9). One of them ("CiganijaKrapaćos") is partly situated in the closer riverside, while all the others ("Pajkovo brdo", "Žežnica", "Lipovica", "Cigansko brdo", "Sedlarac", "Straževica", "Dunavski venac" and "Gvozdenglav") are more or less farther.

There are almost half as many farther riverside settlements (4) on the valley sides of the Danube immediate tributaries. Two of them are, partly ("Provalija") or completely ("Tarabe"), situated in the source forehead of the Pravinački stream, so they are also in the farther riverside area of the central waterflow. One ("Dubočaj") is on the sides of a small valley in the down course of the Dubočaj stream, while the other is situated on a valley side of the middle course of the Jugovski stream.

Both the alluvial plane of the Danube and the "rear" slopes of Miroč contain slightly smaller number ( 3 each) of such settlements ("Rovine", "Kalinovac" and "Kalinovčić II" within the former, and "Dobra voda", "Bare" and "Poljana" within the latter macrolocality of the well known Miroč region). Because they are situated on "Miroč terrain", these settlements are the only in the Danube Basin which are rather distant from the far Danube riverside, while the "lowlands" ones are much closer to it, but still within farther riverside.

Farther riverside of both the Aeolian relief and surface edges of Ključ contain one settlement each. The settlement "Male humke" is the only one which belongs to the former, and "Osojna" is the only one in the latter macrolocality.

\section{Conclusion}

The given review of the spatial dispersion of the Danube Basin settlements results in general regularity of their frequency in the determined spatial localities. It indicates that their occurrence is more frequent in the western Danube Basin (the valley side of the Danube on the northernmost slopes of Grocka and Smederevo highlands) and that it is manifested in a noticeably larger area - to some extent the bank zone and larger part of closer and farther riverside. The situation is similar in the central Danube Basin, i.e. "lowlands" and the Aeolian Danube riverside. But approaching its eastern parts, i.e. the surface edges of Ključ, the settlements are less and less frequent and finally they are found only in the shared area between the closer riverside and the bank zone. This may be explained by almost immediate presence of "emanation area", such as Belgrade agglomeration on the one hand, and higher quality which would satisfy the need for changing (sometimes or periodically) the environment, on the other. The influence of these factors is reducing as we go from the west to the east of the Danube Basin, resulting in less frequent and less "voluminous" dispersion of the Danube Basin settlements.

\section{References}

Popović, I. B. 2003. Naseobine za odmor i rekreaciju u Podunavlju na sektoru Beograd - Prahovo. Doktorska disertacija u rukopisu. Departman za geografiju, turizam i hotelijerstvo, PMF, Novi Sad, pp. 1-402.

Gosar, A. 1988. Počitniške hiše kot element transformacije Slovenskih alpskih pokrajin. Doctoral dissertation - Manuscript. Geography Department, Faculty of Philosophy, Ljubljana, pp. 1-359.

Jovičić, Ž. 1967. Gročansko Podunavlje glavni izletnički rejon Beograda. Zbornik radova Geografskog instituta 14 175-187. 